\title{
TMEM127 wt Allele
}

National Cancer Institute

\section{Source}

National Cancer Institute. TMEM127 wt Allele. NCI Thesaurus. Code C95304.

Human TMEM127 wild-type allele is located in the vicinity of 2 q11.2 and is approximately $15 \mathrm{~kb}$ in length. This allele, which encodes transmembrane protein 127 , may be involved in both signal transduction and intracellular protein localization. Mutation of the gene is associated with pheochromocytoma. 